\title{
PENGEMBANGAN BUKU PANDUAN MONITORING PENANAMAN KARAKTER DI PESANTREN PROGRESIF BUMI SHALAWAT SIDOARJO
}

\author{
Robiatul Adawiyah \\ Murtadlo \\ Sri Setyowati \\ Pascasarjana Manajemen Pendidikan Universitas Negeri Surabaya \\ renioktavianti@unesa.ac.id
}

\begin{abstract}
Abstrak: Penelitian pengembangan ini menghasilkan buku panduan monitoring penanaman karakter di pesantren progresif bumi shalawat sidoarjo. Tujuan buku panduan ini sebagai panduan bagi guru dan murobbi/murobbiah dalam memonitoring karakter santri. Buku panduan dikembangkan dengan teori Thiagrajan (1974) dengan melalui 4 tahap four-D yaitu (1) Define (pendefinisian) (2) Design (perancangan), (3) Develop (pengembangan), dan (4) Deseminate (penyebaran). Produk divalidasi oleh ahli bidang MSDM, bidang kepesantrenan serta validasi bidang Bahasa. Pada validasi putaran 1, difokuskan kepada isi dan tulisan buku sehingga validasi didasarkan pada masukan ahli (validasi secara deskriptif). Validasi pada putaran 2 difokuskan pada tingkat kemanfaatan, sistematika, tingkat kejelasan, tingkat keterbacaan, dan aspek kelayakan, petunjuk pemanfaatan buku, kerangka isi buku, uraian isi buku, tingkat ketepatan, dan tingkat kemutakhiran, tingkat kebakuan bahasa buku, dan aspek kebahasaan buku. Kelima ahli memberikan ketegori sangat tinggi untuk tingkat kemnfaatan, tingkat kejelasan, petunjuk pemanfaatan, uraian isi, tingkat ketepatan, tingkat kemutakhiran, dan aspek kebahasaan, kategori tinggi untuk sistematika, tingkat keterbacaan, kerangka isi, dan kebakuan Bahasa, serta kategori cukup untuk aspek kelayakan.
\end{abstract}

Kata kunci: Buku Panduan, Monitoring, Penanaman Karakter, Santri, Pesantren.

Abstract: This research aims to produce a monitoring handbook of character building at Bumi Shalawat Progressive Moslem Boarding. It's purposed as a guidance for murabbi/murobbiah in monitoring the students of moslem boarding school. The development model of this handbook used 4-D, promoted by Thiagarajan (1974), such as (1) define, (2) design, (3) develop, and (4) desseminte. The products were validated by some expert of human resources management, the term of islamic boarding school and the term of language as well. the first round of trial was focused on the quality of content and handbook's writing so that it was carried out descrivtively based on expert suggestion (descriptive validity). while the second round, the focus was in the prototypes' usefulness, systematic, level of clarity, readibility, level of accuracy, the latest aspect, level of language standardness and linguistic aspect. All of the experts marked at a very high level of grade on effectiveness of book, level of clarity, the guideline usage, content frame, level of accuracy, level of latest aspect and linguistic aspect, while the level of sitematic, readibility, frame of content, and language standarness got high category then All aspects scored proper enough for properness aspect.

Keywords : Handbook, monitoring, character bulding, student of moslem boarding school, moslem boarding school.

Pendidikan merupakan investasi kemanusiaan, karena disanalah masa depan peradaban suatu bangsa diproyeksikan. Pendidikan adalah proses pendewasaan manusia. Pendidikan bukan hanya sekedar proses pengalihan pengetahuan dalam arti seluas-luasnya, tetapi juga merupakan suatu proses internalisasi nilai-nilai sosio-kultural dan sosio-religi yang selanjutnya 
dieksternalisasi ke dalam realitas sosial. Jadi, semua potensi yang dimiliki peserta didik, baik kemampuan kognitif, afektif, sosial, dan spiritual harus dikembangkan dan diaktualkan secara sinergis dan bertanggungjawab.

$\mathrm{Hal}$ ini sejalan dengan yang diamanatkan oleh Undang-Undang No 20 Tahun 2003 bahwa pendidikan adalah usaha sadar dan terencana untuk mewujudkan suasana belajar dan proses pembelajaran agar peserta didik secara aktif mengembangkan potensi dirinya untuk memiliki kekuatan spiritual keagamaan, pengendalian diri, kepribadian, kecerdasan, akhlak mulia, serta ketrampilan yang diperlukan dirinya, masyarakat, bangsa dan negara. Dengan cara demikian, maka pendidikan di Indonesia akan mampu melahirkan generasi bangsa yang berkarakter, berkepribadian, dan berbudi pekerti luhur.

Permasalahan yang muncul saaat ini adalah, Pendidikan di Indonesia disibukkan dengan kegiatan yang didominasi pada pengembangan aspek kognitif saja, sehingga banyak orang yang "pintar" namun sedikit orang "benar". Aspek "benar" di sini menyangkut kualitas nilai yang merupakan wujud dari integrasi antara potensi kognitif, efektif, psikomotor, sosial dan spiritual.

Salah satu solusi dari permasalahan Pendidikan yang sedang dihadapi di Indonesia tersebut adalah dengan adanya Pondok Pesantren. Berdasarkan pengamatan awal, konsep pesantren yang full day dan memiliki berbagai unit pendidikan di dalamnya memberikan peluang dan keharusan terhadap banyaknya jenis kegiatan yang ditempuh bagi setiap santri. Hal tersebut mengakibatkan motivasi belajar santri untuk berbagai unit tidak sama, misalkan siswa $A$ rajin berjamaah dan mengaji namun sering tidak mengerjakan PR di sekolah. Di sisi lain, terdapat siswa $B$ yang rajin belajar di sekolah, tetapi malas berjamaah dan mengaji. Berangkat darikondisi tersebut, maka diperlukan adanya pendampingan/monitoring terhadap santri. Pendampingan yang dimaksud adalah pendampingan yang terarah dan menyeluruh yang dilakukan secara terintegrasi. Berangkat dari sisnilah, maka diperlukan panduan pelaksanaan monitoring penenaman karakter.

Depdiknas (2008, p.6-7) memaparkan bahwa menurut Permendiknas No. 2 tahun 2008, buku pedoman pendidikan adalah buku yag memuat prinsip, prosedur, deskripsi materi pokok, atau model pembelajaran yang digunakan oleh para pendidik dalam menjalankan tugas pokok dan fungsi sebagai pendidik. Dalam pengertian yang lebih luas, buku panduan pendidikan adalah buku yang materi atau isinya dapat digunakan untuk meningkatkan kinerja pendidik dan/atau tenaga kependidikan.

Effendy (1989) menyatakan buku panduaan adalah buku yang berisi informasi, petunjuk, dan lain-lain yang menjadi petunjuk tuntunan bagi pembaca untuk mengetahui sesuatu secara lengkap.

Pusat Bahasa Depdiknas (Kemendiknas, 2010) mendefinisikan karakter sebagai bawaan, hati, jiwa, kepribadian, budi pekerti, perilaku, personalitas, sifat, tabiat, watak. Mulyasa \& Hariyanto (2011, p.46) menyatakan pendidikan karakter adalah upaya terencana menjadikan peserta didik mengenal, peduli, dan menginternalisasikan nilai-nilai sehingga peserta didik berperilaku sebagai insan kamil. Affandi (2011) menyebutkan nilai-nilai yang dikembangkan dalam pendidikan karakter diidentifikasi dari sumber agama, pancasila, budaya, dan tujuan pendidikan nasional.

Calyton dan Petry (1983) menyatakan monitoring sebagai suatu proses mengukur, mencatat, mengumpulkan, memproses, dan mengkomunikasikan informasi untuk membantu pengambilan keputusan manajemen program.

Buku panduan monitoring penanaman karakter berisi panduan untuk membantu wali kelas dan murobbi/murobbiah dalam membiasakan dan mengontrol perkembangan karakter santri secara berkala, intens, terintegrasi dan holistik sebagai wujud proses monitoring.

\section{METODE}

Penelitian pengembangan ini menghasilkan buku panduan monitoring penanaman karakter di pesantren progresif bumi shalawat sidoarjo. Tujuan buku 
panduan ini sebagai panduan bagi guru dan murobbi/murobbiah dalam memonitoring karakter santri.

Proses pengembangan buku panduan monitoring ni menggunakan pendekatan metode four $D$ Thiagarajan. Menurut Thiagrajan (1974), dalam pengembangan suatu produk terdapat 4 tahap yang dilalui yang dikenal dengan four-D yaitu (1) Define (pendefinisian) untuk mengidentifikasi munculnya permasalahan mendasar, (2) Design (perancangan) untuk mendesain pola dan isi buku panduan yang meliputi menyusun dan membreakdown nilai-nilai karakter ke dalam program di pesantren, (3) Develop (pengembangan) yang meliputi validasi dan ujicoba lapangan, dan (4) Deseminate (penyebaran) untuk mendistribusikan buku hasil pengembangan.

Prosedur pengembangan buku panduan monitoring dan buku rapor monitoring terhadap pendidikan karakter santri menggunakan prosedur Thiagarajan seperti gambar 1 sebagai berikut.

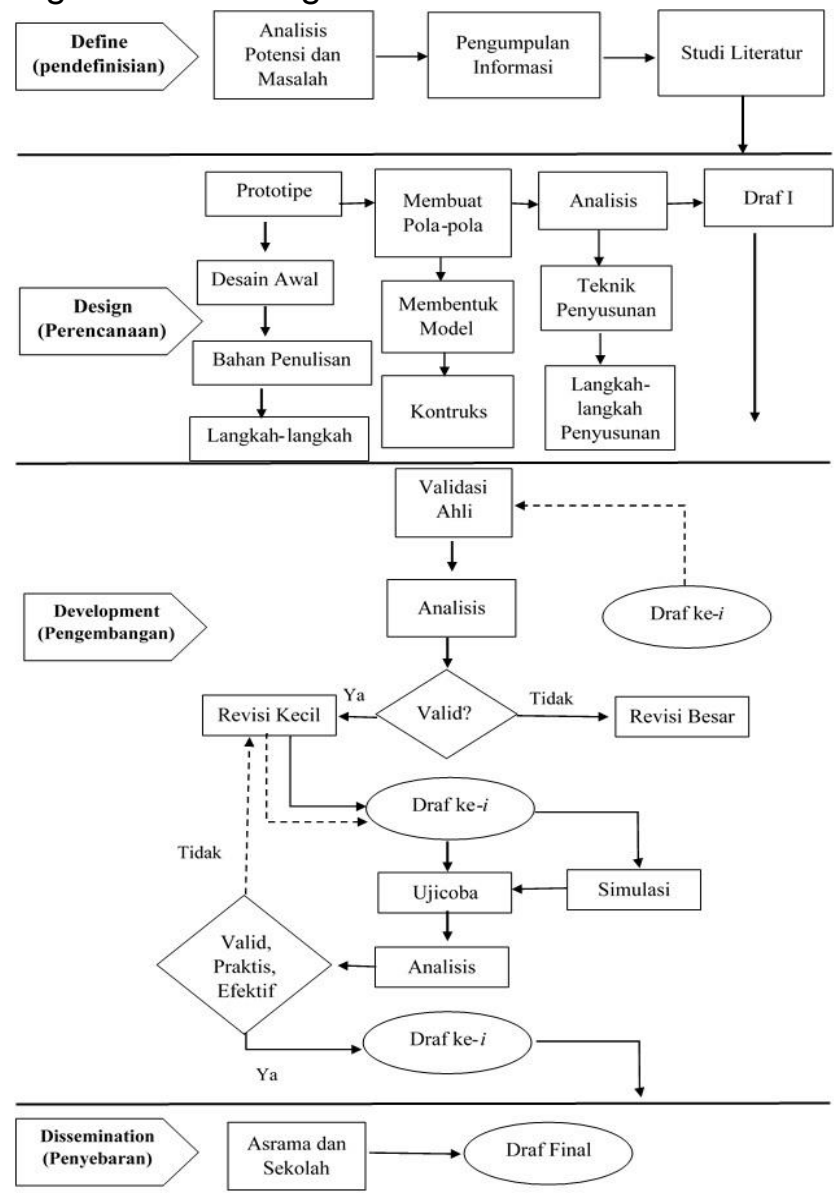

Gambar 1 Diagram Alir Prosedur Pengembangan dengan Model Four-D oleh Thiagarajan
Pada tahap define dalam penelitihan ini, peneliti mengamati dan mengidentifikasi permasalahan tentang monitoring yang terjadi di Pesantren Progresif Bumi Sholawat. Pada tahap design, peneliti mencoba untuk merancang sebuah buku panduan yang menjadi draft 1 dalam penelitian ini. Draft 1 tersebut kemudian akan dikembangkan melalui proses validasi, perbaikan, ujicoba, dan perbaikan kembali sehingga menjadi draft akhir pada tahap development. Proses validasi dilakukan dalam dua tahapan. Validasi oleh ahli dan validasi lapangan.

Pada tahap validasi ahli, produk divalidasi oleh ahli bidang MSDM yaitu Prof. Dr. H. Yusuf Irianto, M. Com, Dr. Karwanto, M. Pd., dan Dr. Totok Suyanto, validasi bidang kepesantrenan oleh $\mathrm{Dr}$. Hj. Luluk Zahro Maulidia. M.Pd, serta validasi bidang Bahasa oleh Dr. Syamsul Sodiq. Pada validasi putaran 1, difokuskan kepada isi dan tulisan buku sehingga validasi didasarkan pada masukan ahli (validasi secara deskriptif). Validasi pada putaran 2 difokuskan pada tingkat kemanfaatan, sistematika, tingkat kejelasan, tingkat keterbacaan, dan aspek kelayakan, petunjuk pemanfaatan buku, kerangka isi buku, uraian isi buku, tingkat ketepatan, dan tingkat kemutakhiran, tingkat kebakuan bahasa buku, dan aspek kebahasaan buku.

Pada tahap validasi lapangan, produk diujicobakan kepada 20 wali kelas dan 10 murobbi/murobbiah yang ada di Pesantren Progresif Bumi Shalawat. Validasi lapangan dilakukan menggunakan instrumen yang terlebih dahulu diuji tingkat validitas dan reliabilitasnya. Berikut persamaan yang digunakan untuk uji validitas menggunakan korelasi Product Moment Pearson.

$$
r_{X Y}=\frac{n \sum X Y-\sum X \sum Y}{\sqrt{\left(n \sum X^{2}-\left(\sum X\right)^{2}\right)^{2}\left(n \sum Y^{2}-\left(\sum Y\right)^{2}\right)}}
$$

Keterangan :

$r_{X, Y}=$ Koefisien korelasi antara pertanyaan $\mathrm{X}$ dan $\mathrm{Y}$

$n=$ Jumlah responden

$\sum X=$ jumlah skor butir soal $\mathrm{X}$

$\sum Y=$ jumlah skor butir soal $Y$

$\sum X^{2}=$ jumlah skor kuadrat butir soal $X$

$\sum Y^{2}=$ jumlah skor kuadrat butir soal $Y$ 
Berikut persamaan yang digunakan dalam uji reliabilitas menggunakan Cronbach's Alpha.

$$
r=\left[\frac{k}{k-1}\right]\left[1-\frac{\sum \sigma_{b}^{2}}{\sum \sigma_{t}^{2}}\right]
$$

dimana,

$r=$ koefisien reliabilitas instrument

$k$ = banyaknya butir pertanyaan yang sahih

$\sum \sigma_{b}^{2}=$ Jumlah varian butir

$\sum \sigma_{t}^{2}=$ varian skor total

Nilai tingkat keandalan Cronbach's Alpha dapat dilihat pada tabel 1 berikut.

Tabel 1 Nilai koefisien Cronbach's Alpha

\begin{tabular}{|c|c|c|}
\hline No & $\begin{array}{l}\text { Nilai Alpha } \\
\text { Cronbanch }\end{array}$ & Keterangan \\
\hline 1 & 0,00 sampai 0,20 & $\begin{array}{l}\text { Kurang } \\
\text { Reliabel }\end{array}$ \\
\hline 2 & $>0,20$ sampai 0,40 & $\begin{array}{c}\text { Agak } \\
\text { Reliabel }\end{array}$ \\
\hline 3 & $>0,40$ sampai 0,60 & $\begin{array}{l}\text { Cukup } \\
\text { Reliabel }\end{array}$ \\
\hline 4 & $>0,60$ sampai 0,80 & Reliabel \\
\hline 5 & $>0,80$ sampai 1,00 & $\begin{array}{l}\text { Sangat } \\
\text { Reliabel }\end{array}$ \\
\hline
\end{tabular}

Sumber : Hair et al. (2010 : 125)

Setelah dilakukan uji validitas dan uji reliabilitas instrumen, maka dilakukan uji validasi produk melalui nilai angket/instrument yang telah terkumpul.

Setelah dilakukan uji validitas terhadap produk, kemudian dilanjutkan dengan uji efektivitas produk menggunakan metode before after dengan bantuan teknik analisis statistik Wilcoxon Signed rank Test. Langkah-langkah dalam uji Wilcoxon Signed rank Test adalah sebagai berikut.

1. Menentukan hipotesis:

Ho: Tidak ada perbedaan sebelum dan sesudah membaca buku panduan

$\mathrm{H} 1$ : Ada perbedaaan sebelum dan sesudah membaca buku panduan

2. Menentukan taraf nyata $(\alpha)$

3. Langkah-langkah pengujian:

a. Berikan jenjang (rank) untuk tiap beda dari pasangan pengamatan (yi - xi) sesuai dengan besarnya, dari yang terkecil sampai terbesar tanpa memperhatikan tanda dari beda itu (nilai beda absolut). b. Bila ada dua atau lebih beda yang sama, maka jenjang untuk tiap-tiap beda itu adalah jenjang rata-rata

c. Bubuhkan tanda positif atau negatif pada jenjang untuk tiap beda sesuai dengan tanda dari beda itu. Beda 0 tidak diperhatikan

d. Jumlahkan semua jenjang bertanda positif atau negatif, tergantung dari mana yang memberikan jumlah yang lebih kecil setelah tandanya dihilangkan. Notasi jumlah jenjang yang lebih kecil ini dengan $\mathrm{T}$

e. Bandingkan nilai $T$ yang diperoleh dengan nilai t uji Wilcoxon

4. Kriteria pengujian :

Ho diterima apabila $t \geq t_{\alpha}$

Ho ditolak apabila $t<t_{\alpha}$

Produk dikatakan efektif jika hasil uji menyimpulkan bahwa Ho ditolak, dengan kata lain $\mathrm{H} 1$ diterima yang berarti ada perbedaaan sebelum dan sesudah membaca buku panduan.

Pemilihan metode ini didasarkan pada distribusi data terkumpul yang tidak normal. Ketidaknormalan data diketahui dengan uji Saphiro Wilk dengan formula sebagai berikut.

$$
T_{3}=\frac{1}{D}\left[\sum_{i=1}^{k} a_{i}\left(X_{n-i+1}-X_{i}\right)\right]^{2}
$$

dengan,

$D=$ Koefisien uji Saphiro Wilk

$\left(D=\sum_{i=1}^{n}\left(x_{i}-\bar{x}\right)^{2}\right)$

$X_{n-i+1}=$ nilai data ke- $n-i+1$

$X_{i}=$ nilai data ke- $i$

$\bar{x}=$ nilai rata-rata data

\section{HASIL DAN PEMBAHASAN}

Penelitian pengembangan ini menghasil produk berupa buku panduan monitoring penanaman karakter.

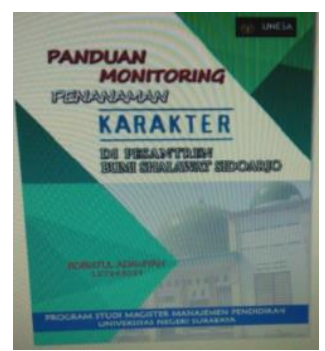

Gambar 2 Tampilan cover buku panduan monitoring 
Buku panduan monitoring penanaman karakter yang dihasilkan terdiri dari : 1) Halaman judul ; 2) Kata pengantar; 3) judul; 4) daftar isi; 5) kata pengantar; 6) BAB I pendahuluan; 7) BAB II perencanaan monitoring; 8) BAB III Pengorganisasian monitoring; 9) BAB IV Pelaksanaan dan pengawasan monitoring; 10) daftar pustaka.

Selain buku panduan monitoring penanaman karakter, produk yang dihasilkan dalam penelitian ini adalah buku raport santri yang merupakan tindak lanjut buku panduan monitoring penanaman karakter. Buku Rapor Santri ini berisi cover, halaman identitas yang terdiri dari nama, nama orang tua, kontak person orang tua, kelas, wali kelas, kamar, murabbi/murobbiah, serta nomor kontak guru dan murabbi/murobbiah, halaman petunjuk pemanfaatan, breakdown program dan peraturan dengan kode pelanggaran dan penghargaan, bentuk sanksi, halaman penilaian yang berisi tabel poin untuk penghargaan, pelanggaran serta jumlah sisa saldo poin, kolom keterangan dan kolom paraf wali kelas/murobbi/ah.

Produk yang telah dihasilkan tersebut, kemudian diuji tingkat validitas dan efektivitasnya yang terdiri dari beberapa tahapan.

\section{A. Uji Validasi Ahli}

Hasil uji validasi ahli yang dilakukan terhadap buku panduan monitoring penanaman karakter adalah sebagai berikut.

\section{Uji Ahli Bidang MSDM}

Tabel 2 Penilaian Ahli Bidang MSDM

\begin{tabular}{llccc}
\hline No & \multicolumn{1}{c}{ Aspek } & \multicolumn{3}{c}{ Penilaian Ahli } \\
& \multicolumn{1}{c}{ Kemanfaatan } & 13 & 12 & 12 \\
$\mathbf{2}$ & Sistematika & 23 & 24 & 22 \\
& Buku & & & \\
$\mathbf{3}$ & Kejelasan & 17 & 22 & 20 \\
$\mathbf{4}$ & Kebahasan & 6 & 8 & 8 \\
$\mathbf{5}$ & Kelayakan & 24 & 29 & 30 \\
\hline
\end{tabular}

Berdasarkan tabel 2, dapat disimpulkan bahwa hasil uji validasi ahli bidang MSDM untuk aspek kemanfaatan, ahli 1 dan ahli 2 memberikan skor sangat tinggi, ahli 3 memberikan skor tinggi. Pada aspek sistematika buku panduan, ahli1, ahli 2, dan ahli 3 memberikan skor tinggi. Pada Aspek kejelasan, ahli 1 dan ahli 3 memberikan skor tinggi sedangkan ahli 2 memberikan skor sangat tinggi. Pada aspek kebahasaan, ahli 1 memberikan skor cukup sedangkan ahli 2 dan ahli 3 memberikan skor tinggi. Pada aspek kelayakan, ahli 1 memberikan skor cukup sedangkan ahli 2 dan ahli 3 memberikan skor tinggi

\section{Uji Ahli Bidang Kepesantrenan}

Tabel 3 Penilaian Ahli Bidang Kepesantrenan

\begin{tabular}{clc}
\hline No & \multicolumn{1}{c}{ Aspek } & $\begin{array}{c}\text { Penilaian } \\
\text { Ahli }\end{array}$ \\
\hline $\mathbf{1}$ & Petunjuk pemanfaatan & 9 \\
$\mathbf{2}$ & Kerangka Isi & 26 \\
$\mathbf{3}$ & Uraian Isi & 17 \\
$\mathbf{4}$ & Kemanfaatan & 17 \\
$\mathbf{5}$ & Kemutakhiran & 22 \\
$\mathbf{6}$ & Ketepatan & 12 \\
$\mathbf{7}$ & Kebakuan bahasa & 12 \\
\hline
\end{tabular}

Berdasarkan tabel 3, dapat disimpulkan bahwa hasil uji validasi ahli bidang kepesantrenan untuk aspek petunjuk pemanfaatan, uraian isi buku, kemanfaatan, kemutakhiran, dan ketepatan, ahli memberikan skor sangat tinggi. Sedangkan untuk aspekkerangka isi dan kebakuan Bahasa, shli memberikan skor tinggi.

\section{Uji Ahli Bidang Kebahasaan}

Tabel 4 Penilaian Ahli Bidang Kepesantrenan

\begin{tabular}{ccc}
\hline No & Aspek & Penilaian Ahli \\
\hline $\mathbf{1}$ & Kebahsaan & 35 \\
\hline
\end{tabular}

Berdasarkan tabel 4, dapat disimpulkan bahwa hasil uji validasi ahli bidang kebahasaan, ahli memberikan skor sangat tinggi.

B. Ujicoba Produk

1. Uji Validasi Lapangan

a. Uji Validasi Instrumen

Tabel 5 Hasil Uji Validitas Instrumen untuk Buku Panduan Monitoring Penanaman Karakter

\begin{tabular}{cccc}
\hline $\begin{array}{c}\text { No } \\
\text { Item }\end{array}$ & $\begin{array}{c}\text { Corrected } \\
\text { Item-Total } \\
\text { Correlation }\end{array}$ & -tabel & Keterangan \\
\hline Item_1 & 0,632 & & Valid \\
Item_2 & 0,833 & & Valid \\
Item_3 & 0,827 & & Valid \\
Item_4 & 0,791 &, 3061 & Valid \\
Item_5 & 0,729 & & Valid \\
Item_6 & 0,827 & & Valid \\
\hline
\end{tabular}




\begin{tabular}{|c|c|c|c|}
\hline $\begin{array}{c}\text { No } \\
\text { Item }\end{array}$ & $\begin{array}{l}\text { Corrected } \\
\text { Item-Total } \\
\text { Correlation }\end{array}$ & -tabel & Keterangan \\
\hline Item_7 & 0,833 & & Valid \\
\hline Item_8 & 0,632 & & Valid \\
\hline Item_9 & 0,614 & & Valid \\
\hline Item_-10 & 0,632 & & Valid \\
\hline Item_-11 & 0,827 & & Valid \\
\hline Item 12 & 0,624 & & Valid \\
\hline Item_13 & 0,833 & & Valid \\
\hline Item_14 & 0,827 & & Valid \\
\hline
\end{tabular}

Berdasarakan tabel 5,dapat disimpulkan bahwa instrument yang digunakan dalam uji validitas produk valid dan dapat digunakan.

b. Uji Reliabilitas Instrumen

Tabel 6 Hasil Uji Reliabilitas Instrumen untuk Buku Panduan Monitoring Penanaman Karakter

\begin{tabular}{ccc}
\hline $\begin{array}{c}\text { Banyak } \\
\text { Item }\end{array}$ & $\begin{array}{c}\text { Conbrach's } \\
\text { Alpha }\end{array}$ & Kesimpulan \\
\hline 14 & 0,951 & $\begin{array}{c}\text { Sangat } \\
\text { Reliabel }\end{array}$ \\
\hline
\end{tabular}

Tabel 6 di atas menunjukkan bahwa nilai Cronbach's Alpha yang diperoleh yaitu $0,952>0,80$ sehingga dapat disimpulkan bahwa instrumen yang digunakan untuk buku Panduan Monitoring Penanaman Karakter sangat reliabel dan dapat digunakan dalam penelitian ini.

Berdasarkan rekap data hasil penilaian wali kelas dan Murobbi/murobbiah terhadap buku Panduan Monitoring Penanaman Karakter didapatkan rata-rata skor sebesar 4,21 . Skala yang digunakan dalam analisis data penilaian wali kelas dan Murobbi/murobbiah adalah $0,00-1,00=$ sangat rendah, $1.01-2,00=$ rendah, 2,01 $3,00=$ cukup, $3,01-4,00=$ tinggi, $4,01-5,00=$ sangat tinggi. Berdasarkan skala tersebut, maka dapat disimpulkan bahwa rata-rata skor untuk buku Panduan Monitoring Penanaman Karakter termasuk dalam kategori sangat tinggi.

\section{Uji Efektivitas Produk}

a. Uji Normalitas Data

Tabel 7 Hasil Uji Normalitas Data dengan Saphiro Wilk

\begin{tabular}{|cccc}
\hline Item ke- & Statistik & $\begin{array}{c}\text { Derajat } \\
\text { bebas }\end{array}$ & $\boldsymbol{p}$-value \\
\hline B1 & .577 & 30 & .000 \\
A1 & .492 & 30 & .000 \\
B2 & .554 & 30 & .000 \\
A2 & .404 & 30 & .000 \\
B3 & .554 & 30 & .000 \\
A3 & .452 & 30 & .000 \\
B4 & .554 & 30 & .000 \\
A4 & .180 & 30 & .000 \\
B5 & .526 & 30 & .000 \\
A5 & .180 & 30 & .000 \\
B6 & .597 & 30 & .000 \\
A6 & .347 & 30 & .000 \\
B7 & .597 & 30 & .000 \\
A7 & .275 & 30 & .000 \\
B8 & .554 & 30 & .000 \\
A8 & .347 & 30 & .000 \\
B9 & .597 & 30 & .000 \\
A9 & .433 & 30 & .000 \\
A10 & .275 & 30 & .000 \\
B11 & .597 & 30 & .000 \\
A11 & .452 & 30 & .000 \\
B12 & .597 & 30 & .000 \\
A12 & .492 & 30 & .000 \\
B13 & .404 & 30 & .000 \\
A13 & .347 & 30 & .000 \\
B14 & .404 & 30 & .000 \\
A14 & .347 & 30 & .000 \\
B15 & .275 & 30 & .000 \\
A15 & .492 & 30 & .000 \\
\hline & & & \\
\hline
\end{tabular}

Tabel 4.23 di atas menunjukkan bahwa semua item memilikitue $\mathrm{p}$ value $<\alpha(0,05)$ yang menunjukkan data tidak berdistribusi normal. Dikarenakan data tidak berdistribusi normal, maka untuk uji before-after menggunakan Wilcoxon Signed Rank Test.

b. Uji Before After

Tabel 8 Hasil Uji Wilcoxon Signed Rank Test untuk Uji Before After

\begin{tabular}{cc}
\hline Pair & p-value \\
\hline B1-A1 & 0,001 \\
B2-A2 & 0,001 \\
B3-A3 & 0,002 \\
B4-A4 & 0,008 \\
B5-A5 & 0,005 \\
B6-A6 & 0,000 \\
B7-A7 & 0.001 \\
B8-A8 & 0,002 \\
B9-A9 & 0,005 \\
B10-A10 & 0,002 \\
B11-A11 & 0,000 \\
B12-A12 & 0,000 \\
B13-A13 & 0,008 \\
B14-A14 & 0,008
\end{tabular}


B15-A15

0,005

Berdasarkan tabel 7 di atas diketahui bahwa pada uji Wilcoxon Signed Rank Test untuk menguji $H_{0}$ (Tidak terdapat perbedaan antara subjek peneltian sebelum dan sesudah membaca buku panduan monitoring penanaman karakter) menunjukkan bahwa nilai $p$-value yang dihasilkan kurang dari $\alpha(p-$ value $<a(0,05)$. Hal tersebut menunjukkan bahwa $H_{0}$ ditolak dan $\mathrm{Ha}$ diterima yang berarti terdapat perbedaan antara subjek peneltian sebelum dan sesudah membaca buku panduan monitoring penanaman karakter.

Beberapa penelitian terdahulu yang berakiatan dengan penelitian ini, diantaranya adalah :

Penelitian tentang pendidikan karakter yang berjudul " Integrasi Pendidikan Karakter dalam Pembelajaran IPS untuk Pengamalan Nilai Moral Siswa SMP 1 dan SMP VI di Mataram". Penelitian ini dilakukan oleh Rosada (2009) dari Universitas Negeri Yogyakarta. Penelitian ini mengintegrasikan pendidikan karakter dalam pembelajaran IPS untuk pengamalan nilai moral siswa. Proses integrasi pendidikan karakter siswa diupayakan oleh guru melalui pemberian contoh aplikasi materi dalam kehidupan nyata tidak hanya sekedar konsep atau teori tetapi langsung penerapan teori dalam lingkungan kehidupan. Pembelajaran dilakukan melalui program pemanfaatan metode pembelajaran, media dan pendekatan yang relevan sehingga memberikan motivasi tersendiri untuk siswa dalam belajar IPS sehingga pembentukan karakter dasar siswa dapat tercapai.

Penelitian tentang strategi monitoring yang berjudul "Strategi Monitoring dan Evaluasi (MONEV) Sistem Penjaminan Mutu Internal Sekolah". Penelitian ini dilakukan oleh Asep Suryana, M.Pd dari Universitas Pendidikan Indonesia. Dalam penelitian ini proses monitoring dilakukan terhadap pegawai di sekolah oleh kepala sekolah untuk menjaga mutu pendidik yang akan berdampak langsung terhadap mutu sekolah. Penelitian ini menjadi acuan peneliti meskipun objek penelitiannya berbeda. Dalam penelitian yang akan dilakukan, yang menjadi objek penelitian adalah siswa.

Penelitian tentang pendidikan di Boarding School yang berjudul " Perbedaan
Motivasi Belajar dan Prestasi Belajar pada Siswa yang Menggunakan Sistem Boarding School dan Siswa yang Tidak Menggunakan Sistem Boarding School di SMA Muhammadiyah 1 Gresik" . penelitian ini dilakukan oleh Mai Kurniasari NingTias dan Muhamad Sholeh, S.Pd, M.Pd dari Universitas Negeri Surabaya. Penelitian ini bertujuan untuk mengukur perbedaan motivasi belajar dan prestasi belajar pada siswa yang menggunakan sistem boarding school dan siswa yang tidak menggunakan sistem boarding school. Hasil menunjukkan bahwa terdapat perbedaan yang cukup signifikan tentang motivasi belajar dan prestasi belajar antara siswa yang menggunakan sistem pendidikan berbasis barding dan tidak. Siswa dengan sistem pendidikan berbasis boarding memiliki motivasi dan hasil belajar yang lebih baik. Jika dalam penelitian ini, dilakukan pengawasan dan penilaian terhadap motivasi dan hasil belajar di sekolah boarding, maka yang kan dilakukan penulis adalah pengawasan terhadap pendidikan karakter santri di sekolah boarding.

\section{KESIMPULAN}

Pada proses observasi awal ditemukan permasalahan mendasar yaitu perilaku santri yang masih berubah-ubah. Hal ini disebabkan belum adanya kontrol yang terintregrasi terhadap perkembangan karakter santri. Oleh karenanya disusunlah buku panduan monitoring penanaman karakter bagi wali kelas dan murobbi/murobbiah di pesantren progresif bumi shalawat. Buku panduan disusun berdasarkan langkah-langkah Thiagarajan dengan four-Dnya yaitu (1) Define (pendefinisian) (2) Design (perancangan), (3) Develop (pengembangan), dan (4) Deseminate (penyebaran). Dalam penyusunannanya tidak ditemukan kendala yang berarti sampai produk buku panduan melalui tahap validasi dan uji coba.

Kevalidan buku panduan monitoring penanaman karakter ini dilakukan dengan uji validitas. Uji validitas dilakukan tiga kali, yakni pra validitas oleh dosen pembimbing sampai produk menjadi draf I. draf I divalidasi para ahli MSDM, ahli kepesantrenan, dan ahli bahasa sampai dinyatakan layak. Selanjutnya draf II buku panduan diujikan kepada 30 responden 
untuk mengetahui validitas instrumen dan realibilitas produk yang menggunakan Moment Pearson dan Crombach's Alpha dan hasilnya valid dan reliabel.

Keefektivitasan buku panduan monitoring ini dilakukan dengan uji 30 responden dari wali kelas dan murobbi/murobbiyah dengan uji before after dengan Wilcoxon Signed Rank Test dan hasilnya valid. Hasil pengembangan adalah buku panduan monitoring penanaman karakter yang ditindak lanjuti dengan buku rapor santri.

Hasil penelitian pengembangan ini berupa buku panduan monitoring penanaman karakter di pesantren progresif bumi shalawat sidoarjo yang ditindak lanjuti dengan adanya rapor santri.

\section{DAFTAR RUJUKAN}

Ahmadi, A., \&Widodo, S. (2004). Psikologi Belajar. Jakarta : PT. Rineka Cipta.

Annes, Bambang, Q. (2008). Pendidikan Karakter Berbasis Al-Quran. Bandung : Simbiosa Rektama Pustakarya.

Aqib, Zainal, \& Sujak. (2011). Panduan dan Aplikasi Pendidikan Karakter. Jakarta : Gaung Persada Press.

Banawi, Anasufi. (2009). Keefektifan Model Pembelajaran IPA Berbasis Karakter dalam Meningkatkan Budi Pekerti Siswa Sekolah Dasar (Tesis yang tidak dipublikasikan), Universitas Negeri Yogyakarta, Yogyakarta.

Berger, Roloff, Ewoldsen. (2014). Handbook IImu Komunikasi. Bandung : Penerbit Nusa Indah.

Budiningsih, Asri, C. (2004) pembelajaran Moral : Berpijak pada Karakteristik Siswa dan Budayanya. Jakarta : PT. Rineka Cipta.

Conor. (1974). Monitoring Pekerjaan. Yogyakarta.

Daradjat, Zakiah. (1985). Membina Nilai-nilai Moral di Indonesia. Jakarta : Bulan Bintang.

Dimyati, Mudjiono. (2006). Belajar dan Pembelajaran. Jakarta : Rineka Cipta.
Fahham, Achmad Muchaddam. (2015). Pendidikan Pesantren : Pola Pengasuhan, Pembentukan Karakter, dan Perlindungan Anak. Jakarta : P3DI Setjen DPR RI dan Azza Grafika.

Handayaningrum, W. (2012). Model Manajemen Pelatihan Pendidikan Seni Budaya.Malang : Universitas Negeri Malang.

Handayaningrum, W. (2012). Pengembangan Model Manajemen Pelatihan Pendidikan Seni Budaya bagi Guru SD (Disertasi). Malang : Universitas Negeri Malang.

Haryanto. (2014). Pendidikan Karakter Menurut Ki Hajar Dewantara. Universitas Negeri Yogyakarta, Yogyakarta.

Kemdiknas. (2010). Pendidikan Karakter Terintegrasi dalam Pembelajaran di Sekolah Menengah Pertama. Jakarta : Direktorat PSMP Kemdiknas.

Machfoedz, I., \& Suryani, E. (2007). Pendidikan Kesehatan Bagian dari Promosi Kesehatan. Yogyakarta : Fitrayama.

Maksudin. (2010). Pendidikan Islam Alternatif Membangun Karakter melalui Sistem Boarding School. Yogyakarta : UNY Press.

Marzuki. (2011). Konsep Dasar Pendidikan Karakter. Universitas Negeri Yogyakarta, Yogyakarta.

Muhtadi, Ali. (2010). Strategi Implementasi Pendidikan Budi Pekerti di Sekolah. Majalah Dinamika Pendidikan, 17(1).

Mulyana, D. (2013). Komunikasi Konstektual : Teori dan Praktik Komunikasi Kontemporer. Bandung : PT Remaja Rosdakarya Offset.

Mulyasa. (2011). Manajemen Pendidikan Karakter. Jakarta : PT. Bumi Aksara.

Mun'im, F. (2011). Pendidikan Karakter. Yogyakarta : Ar-Ruzz Media.

Muslich. (2011). Pendidikan Karakter Menjawab Tantangan Krisis Multidimensional. Jakarta : Bumi Aksara. 
Ningtias, M. K., \& Sholeh, M. (2013). Perbedaan Motivasi Belajar dan Prestasi Belajar pada Siswa yang Menggunakan Sistem Boarding School dan Siswa yang Tidak Menggunakan Sistem Boarding School di SMA Muhammadiyah 1 Gresik. E-journal UNESA, 1(1), 2-3.

Pidarta, Made. (2009). Supervisi Pendidikan Kontekstual. Jakarta : Rineka Cipta.

Riduwan. (2014). Manajemen Pendidikan. Bandung : Alfabeta.

Rosada. (2009). Integrasi Pendidikan Karakter dalam Pembelajaran IPS untuk Pengamalan Nilai Moral Siswa SMP 1 dan SMP VI di Mataram (Tesis yang tidak dipublikasikan), Universitas Negeri Yogyakarta, Yogyakarta.

Sudjana. (1986). Metoda Statistik. Bandung : Tarsito.

Sugiyono. (2015). Metode Penelitian dan Pengembangan (Research and Development / R\&D). Bandung : Alfabeta.

Sumarno, Alim. (2012). Perbedaan Penelitian dan Pengembangan. Universitas Negeri Surabaya, Surabaya.

Suryana, Asep. (2010). Strategi Monitoring dan Evaluasi (MONEV) Sistem Penjaminan Mutu Internal Sekolah. Universitas Pendidikan Indonesia, Bandung.

Tatang, Abdullah. (2015). Supervisi Pendidikan. Bandung : CV Pustaka Setia.

Wibowo, Udik Budi. (2010). Pendidikan dari Dalam : Strategi Alternatif Pengembangan Karakter. Universitas Negeri Yogyakarta, Yogyakarta.

Wiryokusumo, Iskandar. (2011). Dasar-dasar Pengembangan Kurikulum. Jakarta : Bumi Aksara.

Winardi, J. (2014). Manajemen Perilaku Organisasi. Jakarta : Prenada Media Group.

Zubaidi. (2011). Desain Pendidikan Karakter. Jakarta : Kencana Prenada Madani.
Zuhriy, M. Syaifudien. (2011). Budaya Pesantren dan Pendidikan Karakter pada Pondok Pesantren Salaf. Journal Walisongo, 19(2). 